\title{
Discussion on Subject Knowledge Service Pattern of Agricultural University Libraries
}

\author{
Linlin Zhang \\ Heilongjiang Bayi Agricultural University Library, Heilongjiang Bayi Agricultural University, Daqing, China \\ Email: liblin@126.com
}

Received 22 November 2015; accepted 23 January 2016; published 26 January 2016

Copyright (C) 2016 by author and Scientific Research Publishing Inc.

This work is licensed under the Creative Commons Attribution International License (CC BY).

http://creativecommons.org/licenses/by/4.0/

(c) (i) Open Access

\begin{abstract}
Taking Heilongjiang Bayi Agricultural University as an example, the discipline service practice was explored from the aspects such as free network resources and tool use, subject navigation, subject librarians, information sharing space and information literacy education. The typical cases were provided; the optimization of utilization method of network resources was put forward; the subject theme navigation was developed; and the information sharing space of specific discipline and other working strategies were carried out. The experience and enlightenment of active service for subject construction, priority service for key subjects, subject service by lay and step and seizing of the opportunity of subject service were summarized, which developed ideas and provided reference to the establishment of deep subject services of general libraries of colleges and universities.
\end{abstract}

\section{Keywords}

Subject Service, Value-Added Service, Knowledge Service, Application Pattern

\section{Introduction}

Subject construction is a long-term and fundamental strategic task of institutions of higher learning, and the key of the development of colleges and universities [1]. Subject service is a new service concept launched by libraries of colleges and universities in order to adapt to the new information environment changes. It is user-centered. Relying on the national literature resource platform and public information service platform, with subject librarians as the medium, it provides highly targeted "one-to-one" service to various departments, laboratories, subject groups or individuals of colleges and universities [2]. The relevant data shows that by the end of 2010 almost all the libraries of 211 colleges and universities have subject services [3]. Subject service is the extension of traditional information consulting service. The service mode and content are more personalized, professional 
and educated, thus ensuring that subject teaching, subject study and individual needs are effectively met. It expands the wider survival and service space for the libraries [4].

The subject knowledge service is a proactive extension service mode, which is implemented by the university libraries under the guidance of the readers' personalized requirements. The Heilongjiang August First Land Reclamation University reorganized the department organizations in 2009 and promoted the main strategy of "subject knowledge service" for all readers in the university via a series of subject knowledge service schemes, which has achieved remarkable effect and been recognized by the readers during 5 years. This paper completely explains the subject knowledge service practice mode of the Heilongjiang August First Land Reclamation University Library in organization architecture, activity plan, service content, service pattern and implementation effect.

\section{Team Cooperation Architecture of "Vertical Promotion + Organization Collaboration"}

Any innovative service pattern should be based on the corresponding organization service mode. To better promote the subject knowledge service in the universities, the libraries should be organized in a vertical and horizontal manner. Different departments should provide effective service pattern for the subject knowledge service based on their features in vertical direction. Different departments should carry out the subject service team cooperation due to work requirements in the horizontal direction [5]. e.g. the library regards the reference resource development department as the main department for promoting this service. This department includes 4 subject librarians. Each subject librarian should cooperate with the collecting and editing persons to compose the subject service team, which will carry out requirement investigation, subject novelty search, reference transfer and reader training in two L2 academies of the university. The system department should cooperate with the subject librarians of reference resource publication department to complete construction of the subject knowledge service platform of the library website. e.g. "Heilongjiang reclamation farm history log database", "precise agricultural database", "network free-electronic full-text database", and "courseware navigation database" established by the library. Such vertical and horizontal organization and cooperation service pattern fully mobilizes work enthusiasm of all librarians and exerts the collective intelligence, so the librarians can further improve their existence value and improve recognition of the society. They can better participate in the subject knowledge service.

\section{3. "Three Promotion + L2 Service" Comprehensive Activity Plan}

To make the subject knowledge service achieve practical and effective role and effect and ensure that the information resources and subject services of the library can meet the requirements of the teachers and readers of the schools, the library will design promotion plan of three services under the guidance of "walk into subject-library beside you", which is described as follows:

\subsection{Promotion of Foundational Service}

The reference collecting and editing department effectively promotes the subject knowledge service in the foundational service of the library and carries out the book recommendation and purchase service by specifying the subject collecting and editing persons to send the subscription bibliography information to teachers in universities and carrying out "you select books and I buy order" activity, subject bibliography recommendation, and interview with the academies and departments and subject leader.

\subsection{Promotion of Virtual Service}

The library assists completion of subject knowledge service by establishing the subject consulting platform, characteristic subject reference resource construction, courseware navigation database construction, embedded IM online consulting, provision of subject professional website, regular sending of academy and department, and email message pushing.

\subsection{Promotion of Academy and Department Service}

The library perfectly transforms from the passive service to active service by walking into academies and departments, and effectively pushes the subject knowledge service to the academies and departments by cooperating 
with the database providers to carry out "operation method of database and reference management software" training seminar for academies and departments, subject tracking service, foreign reference pushing service, and making academic evaluation report and embedded course teaching for subject leaders and research organizations.

The library carries out different subject knowledge services for the service type and service demand of readers. e.g. for the readers with general information demands, focus on omnidirectional promotion and carry out information quality training seminar and rich cultural activities. For users with special information requirements, focus on customized services and provide deep knowledge services such as subject article pushing, academic trend tracking and conference brief report pushing.

\section{Diversified Innovative Service for "Create Brand + Mine Requirement"}

When the university libraries advertise the library service, generally they ignore the brand creation and are lack of the planning, advertisement and operation consciousness, so many welcome cultural activities are temporary and no characteristic brand cultural activities are formed [6]. The Agricultural University library fully considers these factors in the cultural activities with the subject knowledge service as the main line, so the cultural activities welcomed by the readers will be implemented persistently and normally at the beginning of the planning activities in order to build the characteristic cultural brand. For different requirements, with the annual reading day and reader service month as the opportunity, the agricultural university library carries out a series of subject knowledge service promotion activities to perform whole packing, series design and promotion of some independent projects, encourage readers to actively participate in and interact, and enhance the abstraction of the libraries. The library completely builds the fine cultural activities in resource, service and communication, which is described as follows:

\subsection{Resources}

The library holds "Book ocean treasure hunting" book retrieval skill match, I decide my resources-search beside "database Daren" match, database promotion service month, and field consulting table of agricultural university library. The resource promotion activities are held to promote understanding of extensive reads on the library, guide the readers to correctly, fully and efficiently utilize the paper resources and electronic resources of the libraries, and grasp basic methods and skills of the reference retrieval, and drive advertisement and promotion of the paper resources and use of digital resources.

\subsection{Service}

The library holds the graduation paper guide and training ambassador selection activities, "are you ready for postgraduate enrollment examination?" subject seminars, "walk into academies and serve subjects" activities, "love every day of library" micro-film match, good paper recommendation, and "most beautiful library-mobile library experiences". Implementation of these services will further strengthen communication and association between the library and students and teachers in different academies, so the students and teachers in the schools can know the resources and services of the libraries to improve initiative and purpose of the library information service.

\subsection{Communication}

The library will hold "Wang Zhen lecture hall" activity. The culture lecture hall fully shows the intension of the library to expand service fields, strengthen service function, and promote campus culture construction, and is the key platform to improve the comprehensive quality of students. The lecture hall aims to invite the well-known scholars and professors in the university to introduce the latest learning achievement and share their inspiration from the life to the readers via the lectures based on their professional knowledge and cultural background. The library held "Wang Zhen lecture hall" in Mar, 2010. Now "Wang Zhen lecture hall" has been held 100 times and the audiences reach over 6000. It has gradually formed the self-service mode and characteristics, becomes the brand culture of the library, and shows its charm in campus culture construction. The library carries out "agricultural university reads me to you·True person library" activity. This activity encourages readers in the campus to regard themselves as the true person book and share distinct experiences, specialty, skill and inspiration with others. This form not only breaks different rigorous requirements of readers for reading form, contents and range, 
but also encourages bi-directional exchange of students, enhances mutual understanding, and lets students believe themselves as good books. This activity not only makes the readers acquire the curious knowledge, but also provides the small show stage for the "true person book". These cultural activities are successfully held to build the library as the campus culture center, better exert the culture leading role of the library, and promote culture exchange, transfer and propagation.

\section{5. "Stereo Association + Utmost" Linked Service Pattern}

For different subject service schedule, the library cooperates with different units to carry out " $3+x$ ” block service pattern, which is described as follows:

\subsection{Cooperation with Youth League Committee of University}

The digital library construction represents the development direction of the library in the information age. For university students, it is very important to grasp the retrieval method of digital resources. To increase the information acquisition channel of students and make students further recognize and know the digital resources of the library, the library started to cooperate with the Youth League Committee of the university from 2011 and has successfully held "VIP reference knowledge search skill match". In the competition activities, the Youth League Committee of the university is responsible for early advertisement and organization. The library is responsible for training and promotion. Such cooperation carries out the cultural activities of the library via the implementation strategy of “whole planning, step implementation, united guarantee and step-by-step penetration”.

\subsection{Cooperation with Administrative Department of University}

In the university, besides the teaching and R\&D service, the subject knowledge service includes the service for the university's decision department [7]. The science data is the important basis for the scientific evaluation and management. The evaluation office, science and technology division and human resource management division will require the auxiliary data as the basis for decision evaluation. For this current condition, the university library will completely launch the intelligent information service via the personalized and flexible service scheme. We provide the analysis report of "SCI paper published by Agricultural university" by using the strength in information acquisition. Depending on the Cqvip database, we establish the organization knowledge portal of the Heilongjiang August First Land Reclamation University Library to provide academic data evaluation report of the academies and departments of the university, including academic achievement output analysis, main researcher scholar and field analysis, and related research organization analysis, and offset the detailed and reliable evaluation basis for the academy and talent information collection and academic evaluation. The fact proves that that the subject knowledge service can provide reliable policy basis for subject establishment, operation strength and specialty setup, and offset favorable guarantee for long-term development of the university.

\subsection{Cooperation with R\&D Team}

It is difficult for the library service to embed into the R\&D team and provide the subject knowledge service all the time due to restrictions in specialty background and foreign language level. By combining the specialty strength and resource strength, the subject librarians will provide the subject service through the subject research of $R \& D$ team [8]. e.g. when the subject is applied, the library will assist the R\&D persons to search the latest references on the subject. Many R\&D persons cannot select accurate retrieval words in reference search, so they cannot reach the ideal retrieval results. At this time, the subject librarians will provide better recommendations for retrieval word selection to ensure subject novelty. In the subject research, the subject librarians will assist them to collect and acquire the latest academic trend and emergency special references by using the smart tools and deep knowledge discovery tool. After the subject ends, we can assist them to provide novelty search of subject achievements and subject achievement certificate. With the above services, the subject service of the library is trusted and welcomed by the R\&D team more and more.

\section{Full-Coverage Evaluation System of "Fine Test and Evaluation and Interactive Summary"}

To further validate implementation effect of the subject service of the library, the library establishes the subject 
service evaluation system via three modes.

\subsection{Reader Feedback}

The library will interview the teachers and students in the academies and schools in annual reader service month to know the service requirements of teachers and students and improvement of the library in the subject service. The investigation results will provide direct reference for further development of the subject knowledge service.

\subsection{Inter-Department Mutual Evaluation inside Library}

In the annual summary conference of the library, the representatives from different departments and divisions will evaluate the subject service work effect in a face-to-face manner and propose the reasonable improvement comments.

\subsection{Evaluation of R\&D Team}

For the R\&D team of the subject knowledge service, when the subject is completed, the subject service persons should deeply exchange with the R\&D persons of the am, and share experiences and achievements with exerts. Finally experts will propose the subjective comments and recommendations to promote the deep development of the subject service.

The Heilongjiang August First Land Reclamation University Library has successful experiences in implementation of the subject service. With repeated trial, although certain effect is achieved in a short time, it will required a long period to extensively establish equal and mutually beneficial cooperation in the reader group and successfully transform proactive pushing to proactive requirement, so the Heilongjiang August First Land Reclamation University Library should continuously innovate the subject knowledge service contents and explore the subject knowledge service fields in the subject knowledge service in future in order to provide professional, deep and personalized subject knowledge service to extensive readers.

\section{Summary}

In the process of subject service, general libraries of colleges and universities shall first define the positioning of subject service of their own, start from the conditions of the school and library, adjust measures to local conditions, look for the characteristic subject service methods suitable for the library, and avoid blindly copying the mode of major universities; next, they shall give full play to the subjective initiative, use the resources inside and outside the library, and open up a new prospect through focusing on construction and concentrated construction; third, they shall push from the first-level services to high-level services step by step. In addition, the subject service is not completely equal to the scientific research service. For general colleges and universities, especially, the colleges and universities without awarding power of master's and doctor's degree mainly engage in teaching; the teaching service for the undergraduate education is the top priority.

\section{Funding}

Heilongjiang Philosophy and Social Science Plan research project "Information service system building of university libraries in big data age” (project number: 14E045).

Heilongjiang Art and Science Plan co-building project "research on library service innovation development in new media age” (project number: 2014D014).

\section{References}

[1] Zhao, J.N. (2014) Information Commons-Based Subject Service in University Library. Information Research, 195, 119-125.

[2] Fang, F.-Y. (2014) Research on Subject Service in University Library. Journal of Library and Information Sciences in Agriculture, No. 6, 145-147.

[3] Li, G.Z. (2014) Research on the Multi-Collaborative Subject Service of University Libraries. Journal of Modern Information, 34, 147-151.

[4] Gao, Y.-Y. (2015) Research on the Current Situation of Discipline Service in Shaanxi’s University Libraries. Journal 
of Library and Information Sciences in Agriculture, No. 10, 155-158.

[5] Liu, H., Zeng, L. and Li, W.L. (2014) Construction and Evaluation of Subject Knowledge Service System of University Library with Nanjing University of Traditional Chinese Medicine as One Example. University Library Service, 34, 24-27.

[6] Yang, Y.H. (2007) Discussion on Information Marketing and Subject Knowledge Service of University Library. Popular Science \& Technology, No. 8, 153-154.

[7] Ma, Y.B. (2012) Discussion on Core Competition Capability of University Library in Subject Knowledge Service. Intelligence, 23, 327.

[8] Tong, P. (2014) Structure and Pattern of Subject Knowledge Service System of University Library. Journal of Anshan Normal University, 16, 99-102. 